\title{
Multinuclear NMR study of the complexes of 6-phospho-D-gluconic acid with W(VI) and Mo(VI)
}

\author{
M. Luísa Ramos* and Victor M. S. Gil \\ Department of Chemistry, University of Coimbra, P-3004 535 Coimbra, Portugal \\ Received 19 May 2004; accepted 22 June 2004 \\ Available online 29 July 2004
}

\begin{abstract}
Multinuclear $\left({ }^{1} \mathrm{H},{ }^{13} \mathrm{C},{ }^{17} \mathrm{O},{ }^{31} \mathrm{P},{ }^{95} \mathrm{Mo},{ }^{183} \mathrm{~W}\right)$ magnetic resonance spectroscopy (1D and 2D) has been used to show that 6-phospho-D-gluconic acid forms three complexes with tungsten(VI) and six complexes with molybdenum(VI) in aqueous solution, depending on $\mathrm{pH}$ and concentration. Two isomeric 1:2 (metal-ligand) complexes are detected both with tungstate(VI) and molybdate(VI), having $\mathrm{MO}_{2}{ }^{2+}$ centres and involving the carboxylate and the adjacent $\mathrm{OH}$ groups in addition to one 2:1 (metal-ligand) complex possessing a $\mathrm{M}_{2} \mathrm{O}_{5}{ }^{2+}$ centre, with the ligand being coordinated by the carboxylate group and the three consecutive $\mathrm{OH}$ groups in positions 2, 3 and 4. Molybdate(VI) forms three additional species, which are not detected with tungstate. One of them is a 2:1 complex with a $\mathrm{Mo}_{2} \mathrm{O}_{5}{ }^{2+}$ centre, with the ligand being tetradentate via $\mathrm{O}-3, \mathrm{O}-4, \mathrm{O}-5$ and the phosphate group. The other two are 12:4 species, which can be seen as two 1:2 complexes bound together in a ring through two diphosphomolybdate moieties each derived from heptamolybdate by inclusion of two phosphate groups from the ligands.
\end{abstract}

(C) 2004 Elsevier Ltd. All rights reserved.

Keywords: Tungsten; Molybdenum; Complexes; 6-Phospho-D-gluconic acid; NMR

\section{Introduction}

6-Phospho-D-gluconic acid is an intermediate of D-glucose oxidation via the pentose phosphate pathway. ${ }^{1}$ Salts of phospho-D-gluconic acid have also found some applications in material sciences, ${ }^{2,3}$ however, to the best of our knowledge, no studies of the interaction of this acid with metals have been published.

Following our previous studies on the complexes of $\mathrm{Mo}(\mathrm{VI})$ and $\mathrm{W}(\mathrm{VI})$ with sugar derivatives, in particular D-gluconic acid, ${ }^{4}$ we now address the complexation with the important ligand, 6-phospho-D-gluconic acid. The presence of a phosphate group in position 6, instead of an hydroxyl group, is expected to lead to a different complexation behaviour compared to D-gluconic acid.

\footnotetext{
* Corresponding author. Tel.: +351-39-854453; fax: +351-39-827703; e-mail:mlramos@ci.uc.pt
}

\section{Experimental}

Analytical grade disodium tungstate and disodium molybdate dihydrates and commercially available 6-phospho-D-gluconic acid were used.

The $\mathrm{pH}$ was adjusted (cautiously, to reduce the possibility of drastic local disturbances of equilibria that may be slow to disappear) by addition of $\mathrm{DCl}$ and $\mathrm{NaOD}$; the $\mathrm{pH}^{*}$ values quoted are the direct $\mathrm{pH}$-meter readings (room temperature) after standardization with aqueous buffers.

The ${ }^{13} \mathrm{C}$ NMR spectra were obtained on a Varian XL200 instrument and the ${ }^{1} \mathrm{H},{ }^{17} \mathrm{O},{ }^{95} \mathrm{Mo}$ and ${ }^{183} \mathrm{~W}$ spectra were obtained on a Varian Unity-500 NMR spectrometer. The detailed conditions can be found in previous papers. ${ }^{5-8}$ The 2D NMR spectra, DQFCOSY, ${ }^{9}$ HET$\mathrm{COR}^{10}$ and $\mathrm{COLOC},{ }^{11}$ were recorded on a Varian Unity-500 NMR spectrometer. The ${ }^{31} \mathrm{P}$ spectra were obtained on a Varian Unity-500 NMR spectrometer, using $\mathrm{H}_{3} \mathrm{PO}_{4}(85 \%)$ as external reference, $\mathrm{sw}=25,000 \mathrm{~Hz}$, at $=1.0 \mathrm{~s}$ and $d_{1}=5.0 \mathrm{~s}$. 


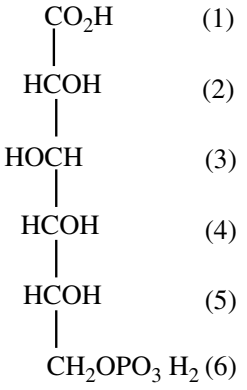

Scheme 1.

\section{Results and discussion}

The Fischer projection of 6-phospho-D-gluconic acid is shown in Scheme 1.
The NMR spectra of mixtures of sodium tungstate or sodium molybdate with 6-phospho-D-gluconic acid, in aqueous solution, show, in addition to those of free ligand, additional ${ }^{1} \mathrm{H},{ }^{31} \mathrm{P}$ and ${ }^{13} \mathrm{C}$ signals due to various complexes. These depend on $\mathrm{pH}$, concentration and metal-ligand molar ratios.

The proton, carbon and phosphorous chemical shifts, as well as the proton-proton and the proton-phosphorous coupling constants, at different $\mathrm{pH}$ are shown in Tables $1-3$, respectively. Where necessary, COSY and HETCOR experiments were performed to assign the proton and carbon shifts. Tables 4-6 present the available ${ }^{17} \mathrm{O},{ }^{183} \mathrm{~W}$ and ${ }^{95} \mathrm{Mo}$ data, respectively. For the free ligand, we found that the ${ }^{1} \mathrm{H}$ and ${ }^{13} \mathrm{C}$ NMR parameters show weak variations with $\mathrm{pH}$, which indicates that no major conformational changes occur. ${ }^{31} \mathrm{P}$ chemical shifts

Table 1. ${ }^{1}$ H NMR parameters ${ }^{a}$ for 6-phospho-D-gluconic acid and its complexes with W(VI) and Mo(VI) (298 K)

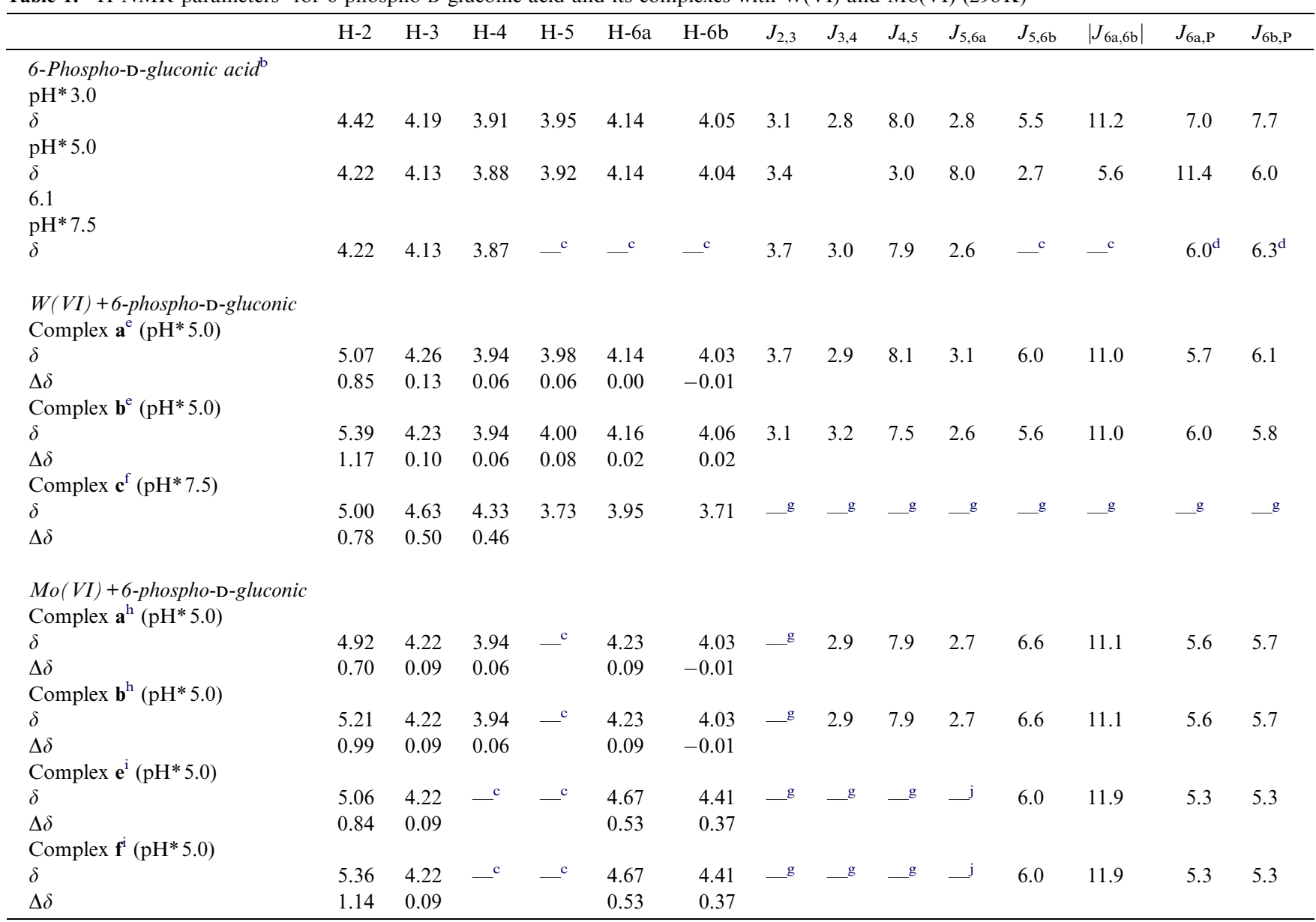

${ }^{\mathrm{a}} \delta$ Values, in ppm, relative to $\mathrm{Me}_{4} \mathrm{Si}$, using tert-butyl alcohol $\left(\delta_{\mathrm{H}}=1.3\right)$ as internal reference; $J$ values in $\mathrm{Hz}$.

${ }^{\mathrm{b}} 0.10 \mathrm{moldm}^{-3}$ 6-Phospho-D-gluconic acid solution.

${ }^{\mathrm{c}}$ Not assigned due to the superposition with other signals.

${ }^{\mathrm{d}}$ Obtained from ${ }^{31} \mathrm{P}$ NMR spectra.

${ }^{\mathrm{e}}$ 0.05:0.10 mol dm ${ }^{-3} \mathrm{~W}(\mathrm{VI})-6$-phospho-D-gluconic acid solution.

${ }^{\mathrm{f}}$ 0.20:0.10 $\mathrm{mol} \mathrm{dm}^{-3} \mathrm{~W}$ (VI)-6-phospho-D-gluconic acid solution.

${ }^{\mathrm{g}}$ Broad signal.

${ }^{\mathrm{h}}$ 0.05:0.10 mol dm ${ }^{-3} \mathrm{Mo}(\mathrm{VI})-6$-phospho-D-gluconic acid solution.

${ }^{\mathrm{i}}$ 0.20:0.10 $\mathrm{mol} \mathrm{dm}^{-3} \mathrm{Mo}(\mathrm{VI})-6$-phospho-D-gluconic acid solution.

${ }^{\mathrm{j}}$ Not obtained due to the proximity of the $H \mathrm{DO}$ signal. 
Table 2. ${ }^{13} \mathrm{C}$ NMR chemical shifts ${ }^{\text {a }}$ for 6-phospho-D-gluconic acid and its complexes with W(VI) and Mo(VI) (298 K)

\begin{tabular}{|c|c|c|c|c|c|c|c|c|}
\hline & $\mathrm{C}-1$ & $\mathrm{C}-2$ & $\mathrm{C}-3$ & $\mathrm{C}-4$ & C-5 & C-6 & $J_{\mathrm{C}-5-\mathrm{P}}$ & $J_{\mathrm{C}-6-\mathrm{P}}$ \\
\hline \multicolumn{9}{|c|}{ 6-Phospho-D-gluconic acid ${ }^{b}$} \\
\hline \multicolumn{9}{|c|}{$\mathrm{pH}^{*} 3.0$} \\
\hline$\delta$ & 178.46 & 74.41 & 72.11 & 72.52 & 71.62 & 67.70 & 7.3 & 4.8 \\
\hline \multicolumn{9}{|c|}{$\mathrm{pH}^{*} 5.0$} \\
\hline$\delta$ & 180.34 & 75.61 & 72.34 & 73.28 & 71.64 & 67.67 & 7.3 & 4.8 \\
\hline \multicolumn{9}{|c|}{$\mathrm{pH}^{*} 7.5$} \\
\hline$\delta$ & 180.50 & 75.75 & 72.42 & 73.39 & 72.15 & 66.57 & 7.3 & 4.8 \\
\hline \multicolumn{9}{|c|}{$W(V I)+6$-phospho-D-gluconic acid } \\
\hline \multicolumn{9}{|c|}{ Complex $\mathbf{a}^{\mathrm{c}}\left(\mathrm{pH}^{*} 5.0\right)$} \\
\hline$\delta$ & 185.48 & 85.99 & 72.35 & 73.28 & 71.94 & 67.56 & 7.2 & 4.6 \\
\hline$\Delta \delta$ & 5.14 & 10.38 & 0.01 & 0.00 & 0.30 & -0.11 & & \\
\hline \multicolumn{9}{|c|}{ Complex $\mathbf{b}^{\mathrm{c}}\left(\mathrm{pH}^{*} 5.0\right)$} \\
\hline$\delta$ & 184.25 & 87.98 & 73.01 & 73.13 & 71.57 & 67.56 & 7.2 & 4.6 \\
\hline$\Delta \delta$ & 3.91 & 12.37 & 0.67 & -0.15 & -0.07 & -0.11 & & \\
\hline \multicolumn{9}{|c|}{ Complex $\mathrm{c}^{\mathrm{d}}\left(\mathrm{pH}^{*} 7.5\right)$} \\
\hline$\delta$ & 187.63 & 85.37 & 83.70 & 82.93 & 73.28 & 67.36 & 7.0 & $-^{\mathrm{e}}$ \\
\hline$\Delta \delta$ & 7.13 & 9.62 & 11.28 & 9.54 & 1.13 & 0.79 & & \\
\hline \multicolumn{9}{|c|}{$\begin{array}{l}M o(V I)+6-p h o s p h o-\text { D-gluconic acid } \\
\text { Complex } \mathbf{a}^{\mathrm{f}}\left(\mathrm{pH}^{*} 5.0\right)\end{array}$} \\
\hline$\delta$ & 184.69 & 86.32 & 72.59 & 73.27 & 71.80 & 67.63 & 7.2 & 4.5 \\
\hline$\Delta \delta$ & 4.35 & 10.71 & 0.25 & -0.01 & 0.16 & -0.04 & & \\
\hline \multicolumn{9}{|c|}{ Complex $\mathbf{b}^{\mathrm{f}}\left(\mathrm{pH}^{*} 5.0\right)$} \\
\hline$\delta$ & 183.34 & 88.09 & 72.59 & 73.27 & 71.80 & 67.63 & 7.2 & 4.5 \\
\hline$\Delta \delta$ & 3.00 & 12.48 & 0.25 & -0.01 & 0.16 & -0.04 & & \\
\hline \multicolumn{9}{|c|}{ Complex $\mathbf{c}^{\mathrm{g}}\left(\mathrm{pH}^{*} 6.0\right)$} \\
\hline$\delta$ & 184.33 & 87.71 & 85.40 & 81.00 & 72.27 & 66.15 & - $^{\mathrm{e}}$ & - $^{\mathrm{e}}$ \\
\hline$\Delta \delta^{\mathrm{h}}$ & 3.99 & 12.10 & 13.06 & 7.72 & 0.63 & -1.62 & & \\
\hline \multicolumn{9}{|c|}{ Complex $\mathbf{d}^{\mathrm{g}}\left(\mathrm{pH}^{*} 7.0\right)$} \\
\hline$\delta$ & 180.97 & 75.50 & $82.01 / /^{\mathrm{i}}$ & $85.55 /^{\mathrm{i}}$ & 83.80 & 66.20 & $\mathcal{-}^{\mathrm{e}}$ & - $^{\mathrm{e}}$ \\
\hline$\Delta \delta^{\mathrm{j}}$ & 0.47 & -0.26 & 8.67 & 12.27 & 11.66 & -0.37 & & \\
\hline \multicolumn{9}{|c|}{ Complex $\mathrm{e}^{\mathrm{g}}\left(\mathrm{pH}^{*} 5.0\right)$} \\
\hline$\delta$ & 184.69 & 86.32 & 72.64 & 73.26 & 71.50 & 69.21 & $\underline{-}^{\mathrm{e}}$ & $\underline{-e}^{\mathrm{e}}$ \\
\hline$\Delta \delta$ & 4.36 & 10.71 & 0.30 & -0.02 & -0.14 & 1.64 & & \\
\hline \multicolumn{9}{|c|}{ Complex $\mathbf{f}^{\mathrm{g}}\left(\mathrm{pH}^{*} 5.0\right)$} \\
\hline$\delta$ & 183.34 & 88.81 & 72.64 & 73.26 & 71.50 & 69.16 & $-^{\mathrm{e}}$ & $\underline{-}^{\mathrm{e}}$ \\
\hline$\Delta \delta$ & 3.00 & 13.20 & 0.30 & -0.02 & -0.14 & 1.48 & & \\
\hline
\end{tabular}

a $\delta$ Values, in ppm, relative to $\mathrm{Me}_{4} \mathrm{Si}$, using tert-butyl alcohol $\left(\delta_{\mathrm{C}} 31.2\right)$ as internal reference; $J$ values in $\mathrm{Hz}$.

${ }^{\mathrm{b}} 0.50 \mathrm{moldm}^{-3}$ 6-Phospho-D-gluconic acid solution.

${ }^{\mathrm{c}} 0.25: 0.50 \mathrm{~mol} \mathrm{dm}^{-3} \mathrm{~W}(\mathrm{VI})-6$-phospho-D-gluconic acid solution.

${ }^{\mathrm{d}}$ 1.0:0.50 $\mathrm{mol} \mathrm{dm}^{-3} \mathrm{~W}(\mathrm{VI})-6$-phospho-D-gluconic acid solution.

${ }^{\mathrm{e}}$ Broad signal.

${ }^{\mathrm{f}}$ 0.25:0.50 $\mathrm{mol} \mathrm{dm}^{-3} \mathrm{Mo}(\mathrm{VI})-6$-phospho-D-gluconic acid solution.

$\mathrm{g}$ 1.0:0.50 mol dm ${ }^{-3} \mathrm{Mo}(\mathrm{VI})-6$-phospho-D-gluconic acid solution.

${ }^{\mathrm{h}}$ Using free ligand $\delta{ }^{13} \mathrm{C}$ values at $\mathrm{pH}^{*} 5.0$.

${ }^{\mathrm{i}}$ The assignment can be reversed.

${ }^{\mathrm{j}}$ Using free ligand $\delta{ }^{13} \mathrm{C}$ values at $\mathrm{pH}^{*} 7.5$.

are more sensitive than other nuclei to $\mathrm{pH}$ values, and thus provide information on the degree of protonation of the ligand phosphate group. Proton and carbon chemical shifts upon complexation are a good indication of the chelation sites of the ligand, however the use of ${ }^{31} \mathrm{P}$ NMR data for the same purpose is more controversial. ${ }^{12-16}$

Spectra of M(VI)-6-phospho-D-gluconic acid (M=W or Mo) were recorded for total species concentration ranging from 3.0 to $0.10 \mathrm{M}$, metal-ligand molar ratios from 10 to 0.25 . The $\mathrm{pH}$ values raised from 2 to 9 for
$\mathrm{W}(\mathrm{VI})$ and from 2 to 8 for $\mathrm{Mo}(\mathrm{VI})$. Three different sets of signals were detected for $\mathrm{W}(\mathrm{VI})$ and six for $\mathrm{Mo}(\mathrm{VI})$. From signal intensity considerations, we concluded that these sets correspond to three complexes for W(VI) and six for Mo(VI). Two of these, namely $\mathbf{a}$ and $\mathbf{b}$, are formed with both metals, at all $\mathrm{pH}$ values, particularly when the metal-ligand molar ratio is less than 1. Species c occurs at pH 5-9 for $\mathrm{W}(\mathrm{VI})$ and 5-7.5 for Mo(VI) and for metal-ligand molar ratios greater than 1. Molybdate can also form three additional species which are not detected in the case of tungstate. Species $\mathbf{d}$ is detected for 
Table 3. ${ }^{31} \mathrm{P}$ NMR chemical shifts ${ }^{\mathrm{a}}$ for 6-phospho-D-gluconic acid and its complexes with W(VI) and Mo(VI) (298 K)

\begin{tabular}{|c|c|c|c|c|c|}
\hline \multicolumn{6}{|c|}{ 6-Phospho-D-gluconic ${ }^{\mathrm{b}}$} \\
\hline $\mathrm{pH}^{*} 3.0$ & \multicolumn{5}{|l|}{1.63} \\
\hline $\mathrm{pH}^{*} 5.0$ & \multicolumn{5}{|l|}{1.91} \\
\hline $\mathrm{pH}^{*} 6.0$ & \multicolumn{5}{|l|}{2.75} \\
\hline $\mathrm{pH}^{*} 7.0$ & \multicolumn{5}{|l|}{4.98} \\
\hline $\mathrm{pH}^{*} 7.5$ & \multicolumn{5}{|l|}{5.23} \\
\hline $\mathrm{pH}^{*} 8.9$ & \multicolumn{5}{|l|}{5.39} \\
\hline \multicolumn{6}{|c|}{$W(V I)+6$-phospho-D-gluconic acid } \\
\hline & Complex $\mathbf{a}^{\mathrm{c}}$ & Complex $\mathbf{b}^{\mathrm{c}}$ & \multicolumn{3}{|l|}{ Complex $\mathbf{c}^{\mathrm{d}}$} \\
\hline $\mathrm{pH}^{*} 3.0$ & 1.61 & 1.58 & & & \\
\hline $\mathrm{pH}^{*} 5.0$ & 1.89 & 1.84 & \multicolumn{3}{|l|}{1.96} \\
\hline $\mathrm{pH}^{*} 6.0$ & 3.42 & 3.14 & \multicolumn{3}{|l|}{3.61} \\
\hline $\mathrm{pH}^{*} 7.0$ & 5.20 & 5.10 & \multicolumn{3}{|l|}{4.70} \\
\hline $\mathrm{pH}^{*} 7.5$ & 5.42 & 5.32 & \multicolumn{3}{|l|}{4.75} \\
\hline \multicolumn{6}{|c|}{$M o(V I)+6$-phospho-D-gluconic acid } \\
\hline & \multicolumn{2}{|c|}{ Complexes $\mathbf{a}+\mathbf{b}^{\mathrm{e}}$} & \multirow[t]{2}{*}{ Complex $\mathbf{c}^{\mathrm{f}}$} & \multirow[t]{2}{*}{ Complex $\mathbf{d}^{\mathrm{f}}$} & Complex $\mathbf{e}^{\mathrm{f}}$ \\
\hline $\mathrm{pH}^{*} 3.0$ & \multicolumn{2}{|c|}{1.70} & & & 2.50 \\
\hline $\mathrm{pH}^{*} 5.0$ & \multicolumn{2}{|c|}{2.16} & & 1.22 & 2.50 \\
\hline $\mathrm{pH}^{*} 6.0$ & \multicolumn{2}{|c|}{3.20} & 3.77 & 1.22 & 2.50 \\
\hline $\mathrm{pH}^{*} 7.0$ & \multicolumn{2}{|c|}{5.60} & 4.66 & 1.22 & 2.50 \\
\hline $\mathrm{pH}^{*} 7.5$ & \multicolumn{2}{|c|}{5.80} & 4.80 & 1.22 & \\
\hline
\end{tabular}

a $\delta$ Values, in ppm, relative to $\mathrm{H}_{3} \mathrm{PO}_{4}(85 \%)$ as external reference.

${ }^{\mathrm{b}} 0.50 \mathrm{moldm}^{-3}$ 6-phospho-D-gluconic acid solution.

${ }^{\mathrm{c}}$ 0.25:0.50 $\mathrm{mol} \mathrm{dm}^{-3} \mathrm{~W}(\mathrm{VI})-6$-phospho-D-gluconic acid solution.

${ }^{\mathrm{d}}$ 0.50:0.25 mol dm ${ }^{-3} \mathrm{~W}(\mathrm{VI})-6$-phospho-D-gluconic acid solution.

${ }^{\mathrm{e}}$ 0.25:0.50 $\mathrm{mol} \mathrm{dm}^{-3} \mathrm{Mo}(\mathrm{VI})$-6-phospho-D-gluconic acid solution.

${ }^{\mathrm{f}}$ 0.50:0.25 mol dm ${ }^{-3} \mathrm{Mo}(\mathrm{VI})-6$-phospho-D-gluconic acid solution.

Table 4. ${ }^{17} \mathrm{O}$ NMR chemical shifts ${ }^{\mathrm{a}}$ for the complexes of 6-phospho-Dgluconic acid with $\mathrm{W}(\mathrm{VI})$ and $\mathrm{Mo}(\mathrm{VI})$, in aqueous solution $(298 \mathrm{~K})$

\begin{tabular}{|c|c|c|}
\hline & $-\underset{\mid}{M}={ }^{17} \mathrm{O}$ & - $\underset{\mid}{\mathrm{M}}-\mathbf{1 7} \mathrm{O}-\stackrel{\mid}{\mathrm{M}}-$ \\
\hline \multicolumn{3}{|c|}{$W(V I)+6$-phospho-D-gluconic acid } \\
\hline Complex $\mathbf{a}^{\mathrm{b}}\left(\mathrm{pH}^{*} 5.0\right)$ & 638 & - \\
\hline Complex $\mathbf{b}^{\mathrm{b}}\left(\mathrm{pH}^{*} 5.0\right)$ & 647 & - \\
\hline Complex $\mathbf{c}^{\mathrm{c}}\left(\mathrm{pH}^{*} 7.5\right)$ & 554,526 & 287 \\
\hline \multicolumn{3}{|c|}{$M o(V I)+6$-phospho-D-gluconic acid } \\
\hline Complex $\mathbf{a}^{\mathrm{d}}\left(\mathrm{pH}^{*} 5.0\right)$ & 836 & - \\
\hline Complex $\mathbf{b}^{\mathrm{d}}\left(\mathrm{pH}^{*} 5.0\right)$ & 845 & — \\
\hline Complex $\mathbf{c}^{\mathrm{e}}\left(\mathrm{pH}^{*} 7.5\right)$ & 790,808 & 342 \\
\hline Complex $\mathbf{d}^{\mathrm{e}}\left(\mathrm{pH}^{*} 5.0\right)$ & 700,709 & 317 \\
\hline \multirow[t]{2}{*}{ Complexes $\mathbf{e}+\mathbf{f}^{\mathrm{e}}\left(\mathrm{pH}^{*} 3.0\right)$} & 864,848 & 323,393 \\
\hline & 836,821 & 496 \\
\hline
\end{tabular}

a $\delta$ Values relative to external reference $\mathrm{D}_{2} \mathrm{O}$.

${ }^{\mathrm{b}}$ 0.25:0.50 mol dm ${ }^{-3} \mathrm{~W}(\mathrm{VI})-6$-phospho-D-gluconic acid solution.

${ }^{\mathrm{c}}$ 1.0:0.50 mol dm ${ }^{-3} \mathrm{~W}(\mathrm{VI})-6$-phospho-D-gluconic acid solution.

${ }^{\mathrm{d}}$ 0.25:0.50 mol dm ${ }^{-3} \mathrm{Mo}(\mathrm{VI})-6$-phospho-D-gluconic acid solution.

e 1.0:0.50 mol dm ${ }^{-3} \mathrm{Mo}(\mathrm{VI})-6$-phospho-D-gluconic acid solution.

metal-ligand molar ratios greater than 1 for the $\mathrm{pH}$ range 5.0-7.5. Species e is detected up to $\mathrm{pH} 6$ for solutions having metal-ligand molar ratios greater than 1 .

The way in which the concentrations of the various species varied with $\mathrm{pH}$ is shown in Figures 1 and 2, for tungstate and molybdate for two different molar ratios, respectively. The approximate concentrations of
Table 5. ${ }^{183} \mathrm{~W}^{\mathrm{a}}$ NMR chemical shifts for $\mathrm{W}(\mathrm{VI})+6$-phospho-Dgluconic (298 K)

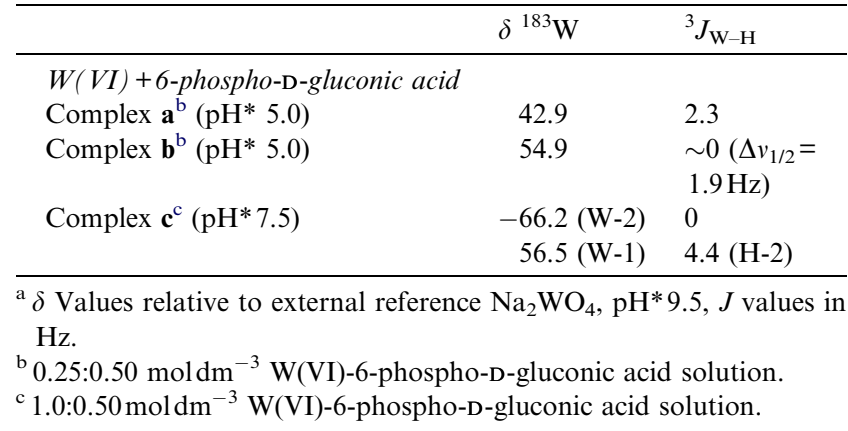

Table 6. ${ }^{95} \mathrm{Mo}$ NMR chemical shifts ${ }^{\mathrm{a}}$ for $\mathrm{Mo}(\mathrm{VI})+6$-phospho-Dgluconic acid (298 K)

\begin{tabular}{|c|c|c|}
\hline & $\delta{ }^{95} \mathrm{Mo}$ & $\Delta v_{1 / 2}$ \\
\hline \multicolumn{3}{|c|}{ Mo $(V I)+6$-phospho-D-gluconic acid } \\
\hline Complex $\mathbf{a}^{\mathrm{b}}\left(\mathrm{pH}^{*} 5.0\right)$ & 98 & 327 \\
\hline Complex $\mathbf{b}^{\mathrm{b}}\left(\mathrm{pH}^{*} 5.0\right)$ & 105 & 263 \\
\hline \multirow[t]{2}{*}{ Complex $\mathbf{c}^{\mathrm{c}}\left(\mathrm{pH}^{*} 6.0\right)$} & 100 & 244 \\
\hline & 30 & 579 \\
\hline \multirow[t]{2}{*}{ Complex $\mathbf{d}^{\mathrm{c}}\left(\mathrm{pH}^{*} 7.0\right)$} & -1 & 338 \\
\hline & 34 & 444 \\
\hline \multirow[t]{2}{*}{ Complexes $\mathbf{e}+\mathbf{f}^{\mathrm{c}}\left(\mathrm{pH}^{*} 3.0\right)$} & -60 & 328 \\
\hline & 99 & 377 \\
\hline
\end{tabular}


the complexes are essentially based on ${ }^{31} \mathrm{P}$ signal intensities, and are compared with the ${ }^{1} \mathrm{H}$ and ${ }^{13} \mathrm{C}$ signal intensities when possible (as usual, the carboxylate signals were excluded due to the long relaxation times).

The observations mentioned above and the analogy with similar systems previously studied point to $1: 2$ stoichiometries in the case of $\mathbf{a}$ and $\mathbf{b}$ and $n: m$ (with $n>m$ ) for the remaining species $\mathbf{c}, \mathbf{d}, \mathbf{e}, \mathbf{f}$. This is confirmed below.

\subsection{1:2 (Metal-ligand) complexes}

As far as complexes $\mathbf{a}$ and $\mathbf{b}$ are concerned, the tungsten and molybdenum shifts are characteristic of isomeric $1: 2$ (metal-ligand) complexes with $\alpha$-hydroxyacids possessing a $\mathrm{MO}_{2}{ }^{2+}$ centre. ${ }^{4-8,17-21}$ The oxygen shifts are typical of terminal $\mathrm{M}=\mathrm{O}$ groups, and there is no evidence for any bridging oxygen atoms. ${ }^{4,6-8,17-19,22-26}$ The high frequency shifts observed for the carboxylic and the adjacent carbinol $\mathrm{C}$ nuclei are characteristic of the involvement of these groups in complexation, ${ }^{4-8,17-19,21,27-33}$ the other carbon shifts upon complexation are much smaller. Accordingly, only the proton $\mathrm{H}-2$ undergoes a significant chemical shift
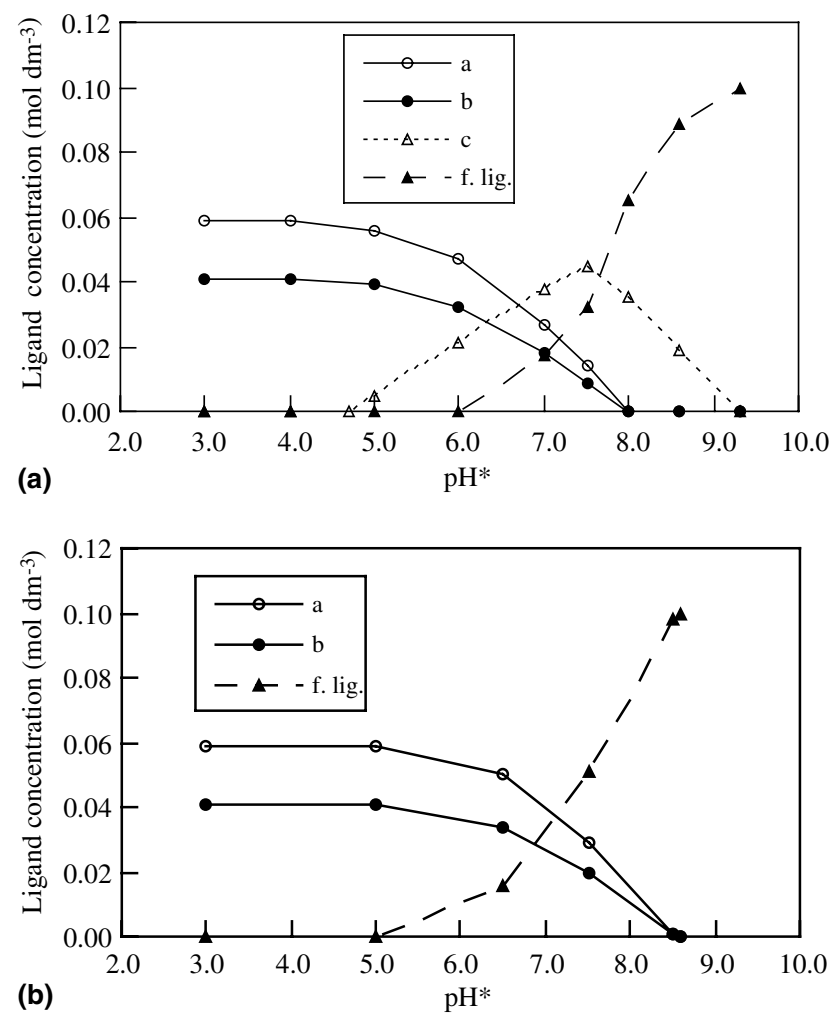

Figure 1. Concentration of the ligand as a function of $\mathrm{pH}^{*}$, obtained by ${ }^{1} \mathrm{H},{ }^{31} \mathrm{P}$ and ${ }^{13} \mathrm{C}$ NMR for (a) a $0.20: 0.10 \mathrm{moldm}^{-3}$ solution in $\mathrm{D}_{2} \mathrm{O}$ of sodium tungstate(VI) and 6-phospho-D-gluconic acid, temperature $298 \mathrm{~K}$ and (b) a $0.05: 0.10 \mathrm{moldm}^{-3}$ solution in $\mathrm{D}_{2} \mathrm{O}$ of sodium tungstate(VI) and 6-phospho-D-gluconic acid, temperature $298 \mathrm{~K}$.
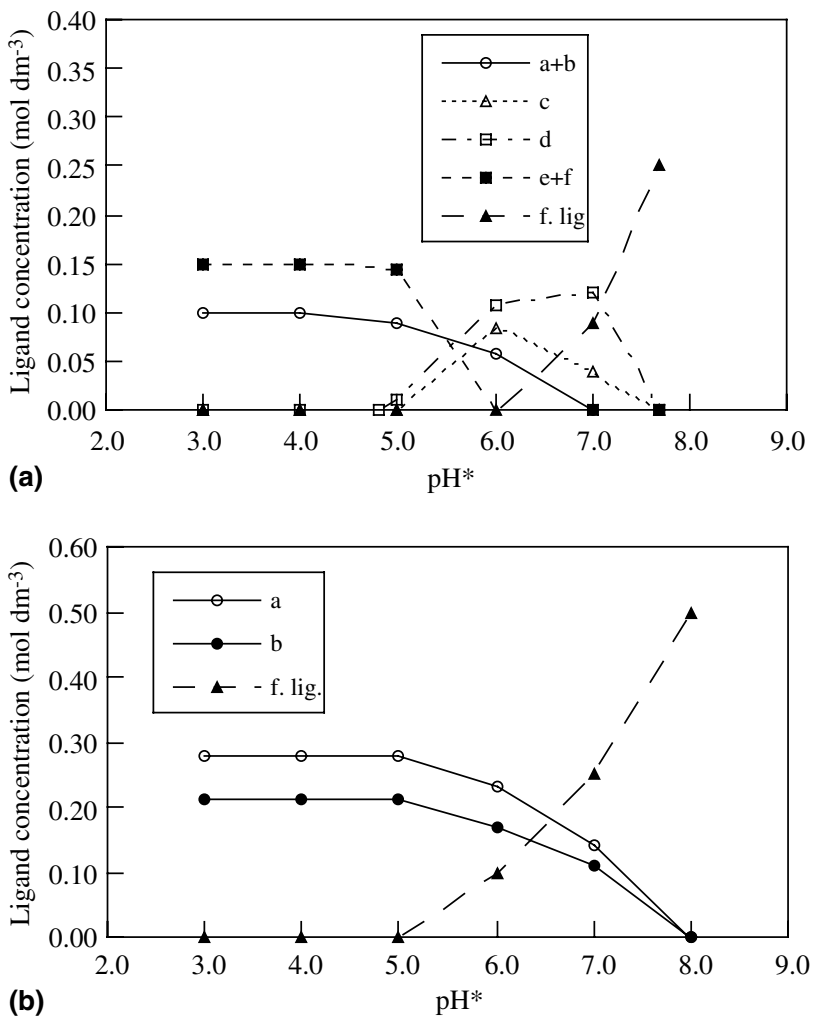

(b)

Figure 2. Concentration of the ligand as a function of $\mathrm{pH}^{*}$, obtained by ${ }^{31} \mathrm{P}$ and ${ }^{13} \mathrm{C}$ NMR for (a) a $0.50: 0.25 \mathrm{moldm}^{-3}$ aqueous solution $\left(33 \% \mathrm{D}_{2} \mathrm{O}\right)$ of sodium molybdate(VI) and 6-phospho-D-gluconic acid, temperature $298 \mathrm{~K}$ and (b) a $0.25: 0.50 \mathrm{~mol} \mathrm{dm}^{-3}$ aqueous solution $(33 \%$ $\mathrm{D}_{2} \mathrm{O}$ ) of sodium molybdate(VI) and 6-phospho-D-gluconic acid, temperature $294 \mathrm{~K}$.

change to high frequency. ${ }^{31} \mathrm{P}$ spectra show two signals, and there are no significant shifts relative to the free ligand over the whole $\mathrm{pH}$ range studied (Figs. 3 and 4). All these findings, associated with the fact that the two ligand molecules are magnetically equivalent, point to a and $\mathbf{b}$ being the diastereoisomers II (Scheme 2) and III (Scheme 3).

Since complex a is slightly more stable than $\mathbf{b}$, steric considerations involving the $\mathrm{R}$ chains would suggest that $\mathbf{a}$ is II and $\mathbf{b}$ is III. These geometries are also consistent with the fact that only small changes of the proton coupling constants are observed upon complexation, and the observation of a small vicinal $\mathrm{W}-\mathrm{H}-2$ coupling constant. In addition, the fact that $\mathrm{H}-2$ in structure II is more affected by the magnetic anisotropy associated with $\mathrm{M}=\mathrm{O}$ groups, leading to a higher screening constant, is in accordance with a smaller $\delta$ value for complex a. Similar complexes have been found for systems previously studied. ${ }^{4,8,17-21,27-33}$ This proposal is supported by a recent study, where the most stable isomer of tungstate and D-(-)quinic acid (potassium bis(quinato)tungstate hydrate) was isolated from an aqueous solution and characterized by X-ray diffraction. $^{33}$ 


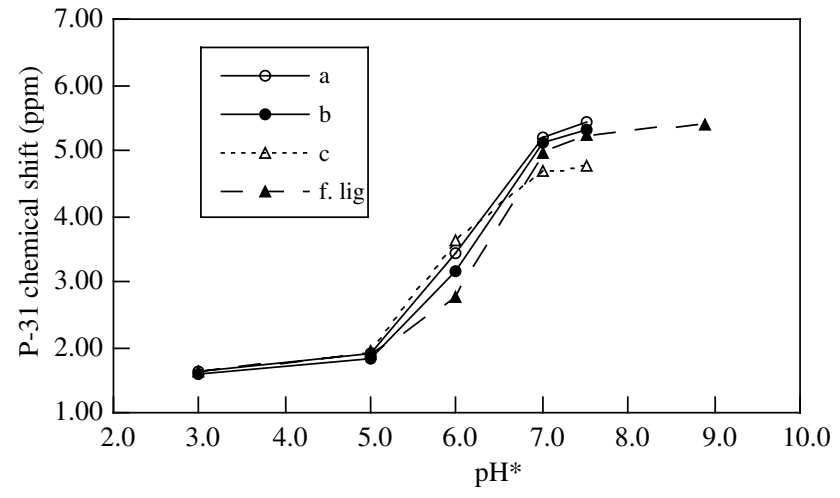

Figure 3. ${ }^{31} \mathrm{P}$ chemical shifts as a function of $\mathrm{pH}^{*}$ for 6-phospho-Dgluconic acid and its complexes with W(VI) (see Table 3).

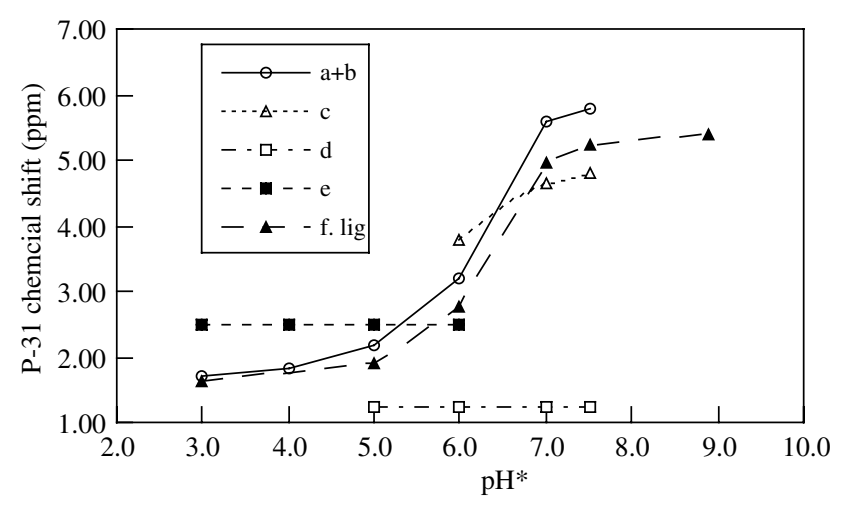

Figure 4. ${ }^{31} \mathrm{P}$ chemical shifts as a function of $\mathrm{pH}^{*}$ for 6-phospho-Dgluconic acid and its complexes with and Mo(VI) (see Table 3).

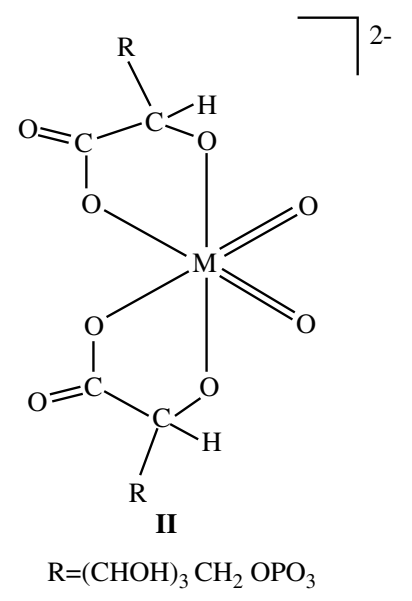

Scheme 2.

\subsection{2:1 (Metal-ligand) complex}

Complex $\mathbf{c}$ is detected, both with tungstate and molybdate, in the $\mathrm{pH}$ ranges 5-9 and 6-7.5 for $\mathrm{W}(\mathrm{VI})$ and Mo(VI) systems, respectively, for solutions with metal-

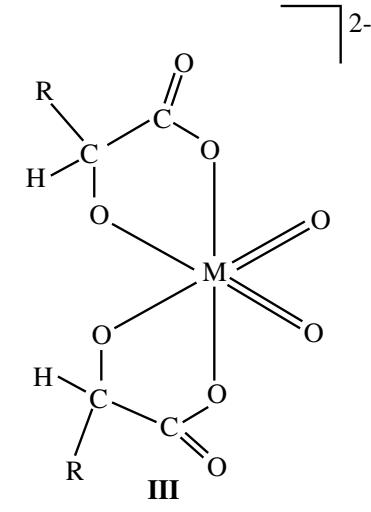

$\mathrm{R}=(\mathrm{CHOH})_{3} \mathrm{CH}_{2} \mathrm{OPO}_{3}$

Scheme 3.

ligand molar ratios greater than 1 . The available ${ }^{13} \mathrm{C}$ and ${ }^{1} \mathrm{H}$ NMR parameters point to the involvement of $\mathrm{O}-2, \mathrm{O}-3$ and $\mathrm{O}-4$ in complexation, in addition to the carboxylate group. Only one ${ }^{31} \mathrm{P}$ signal is detected, showing no significant shift relative to the free ligand at any $\mathrm{pH}$ studied as presented in Figures 3 and 4. This suggests that the phosphate group is not involved with the metal in species c. Complex $\mathbf{c}$ is probably a tetradentate species possessing the central diol group in a threo configuration, with the ligand being in a zig-zag arrangement. The ${ }^{183} \mathrm{~W}$ NMR spectrum shows two signals $(\delta$ -66.2 and $56.5 \mathrm{ppm}$, Table 5). These values can be compared to those found with D-gluconic acid $(\delta-61.8$ and $56.3 \mathrm{ppm}$ ) for an homologous species. COLOC experiments show only a correlation between $\mathrm{W}-1$ and $\mathrm{H}-2$ $\left(J_{\mathrm{W}(1)-\mathrm{H}(2)}=4.4 \mathrm{~Hz}\right)$. A possible structure for complex c is shown in Scheme 4.

The same structure is proposed for $\mathrm{Mo}(\mathrm{VI})$ as suggested by the similar patterns of the ${ }^{1} \mathrm{H},{ }^{13} \mathrm{C}$ and ${ }^{31} \mathrm{P}$ shifts. The ${ }^{95}$ Mo shifts ( $\delta 100$ and $30 \mathrm{ppm}$, Table 6 ) are also very similar to those found for the homologous species detected with D-gluconic acid ( $\delta 95$ and $28 \mathrm{ppm}$ ), and are characteristic of $\mathrm{Mo}_{2} \mathrm{O}_{5}{ }^{2+}$ groups. ${ }^{4,6,17-19,34-36}$ The ${ }^{17} \mathrm{O}$ shifts (Table 4) are characteristic of $\mathrm{Mo}=\mathrm{O}$ and Mo-O-Mo groups, 4,6,8,17-19,22-26 which further supports the proposed structure.

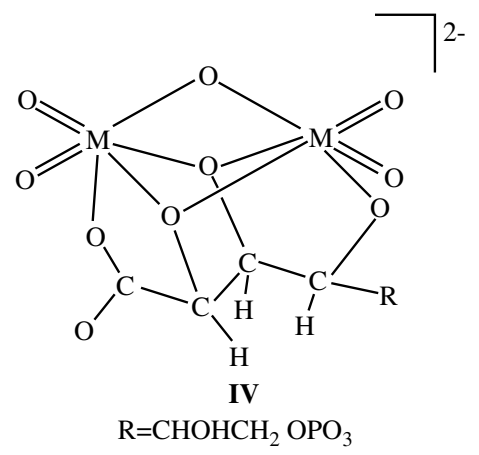

Scheme 4. 


\subsection{Additional species with molybdate}

\subsubsection{Another 2:1 (Metal-ligand) complex at high}

pH. Regarding complex d, which is formed with molybdate above $\mathrm{pH} 5$, proton and ${ }^{13} \mathrm{C}$ resonances are not completely assigned due to the presence of broad lines. However, the ${ }^{13} \mathrm{C}$ shifts observed upon complexation point to the involvement of the $\mathrm{OH}$ groups in positions 3, 4 and 5, with the carboxylate and the adjacent $\mathrm{OH}$ groups being free. The ${ }^{31} \mathrm{P}$ shift $(\delta 1.22 \mathrm{ppm})$ does not change with $\mathrm{pH}$ (Fig. 4). At pH 5 the ${ }^{31} \mathrm{P}$ signal moves to low frequencies $(\Delta \delta-0.69)$ on complexation. Clearly, the phosphate group in $\mathbf{d}$ is in a different situation compared to complexes $\mathbf{a}, \mathbf{b}$ and $\mathbf{c}$. A possible explanation would be the coordination of such a group to the metal centre. The ${ }^{95} \mathrm{Mo}$ shifts ( $\delta 30$ and $-1 \mathrm{ppm}$ ) require a more detailed discussion. The ${ }^{95} \mathrm{Mo}$ shifts, around $30 \mathrm{ppm}$, previously characterized in molybdate complexes of alditols and sugar acids, ${ }^{4,6,8,17-19,34-36,38}$ can be assigned to complexes possessing $\mathrm{Mo}_{2} \mathrm{O}_{5}{ }^{2+}$ centres. In species d, one of the ${ }^{95} \mathrm{Mo}$ shifts ( $\left.30 \mathrm{ppm}\right)$ is in this range, but the other $(-1 \mathrm{ppm})$ is very different. This is probably due to the effect of the phosphate group in making the two molybdenum nuclei magnetically nonequivalent. Complex $\mathbf{d}$ is then probably a tetradentate species, with the coordination being established via the deprotonated $\mathrm{OH}$ groups in positions 3, 4 and 5 and the phosphate group, the carboxylate and the adjacent $\mathrm{OH}$ groups being free, accordingly with the ${ }^{13} \mathrm{C}$ shifts observed upon complexation. The ${ }^{17} \mathrm{O}$ shifts are characteristic of $\mathrm{Mo}=\mathrm{O}$ and $\mathrm{Mo}-\mathrm{O}-\mathrm{Mo}$ groups. ${ }^{4,6-8,17-19,22-26}$ Thus, we propose structure $\mathbf{V}$ for complex $\mathbf{d}$ (Scheme 5).

\subsubsection{2:4 (Metal-ligand) complexes at low and interme-}

diate pH. For species e and $\mathbf{f}$, detected at low and intermediate $\mathrm{pH}$ values with an excess of molybdate, $\mathrm{C}-1$, C-2 and C-6 carbon signals move to high frequency on complexation, as do the $\mathrm{H}-2$ and $\mathrm{H}-6 \mathrm{a}$ and $\mathrm{H}-6 \mathrm{~b}$ proton signals. ${ }^{31} \mathrm{P}$ chemical shifts are not $\mathrm{pH}$ dependent and at $\mathrm{pH} 3$ the ${ }^{31} \mathrm{P}$ signal moves to high frequencies $(\Delta \delta+0.87)$ on complexation. This suggests the involvement of the

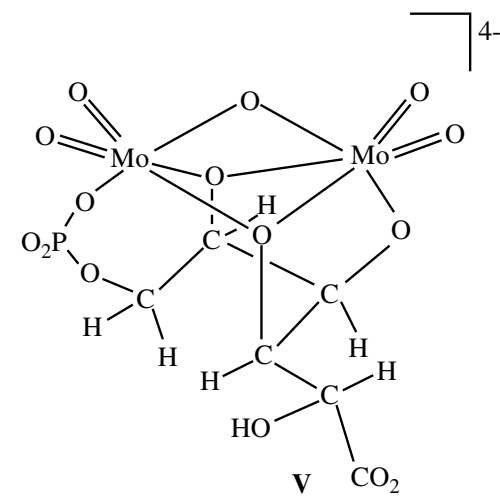

phosphate group with the metal. Similar results were obtained by Geraldes and Castro in the complexation of molybdate with mononucleotides in aqueous solution ${ }^{13}$ and interpreted in terms of the formation of a heteropolymolybdate moiety $\left[\left(\mathrm{OPO}_{3}\right)_{2} \mathrm{Mo}_{5} \mathrm{O}_{15}\right]^{6-} .{ }^{37}$ In fact, the ${ }^{95} \mathrm{Mo}$ spectra show one broad signal with a $\delta$ value $(-60 \mathrm{ppm})$ that has not been previously detected in similar systems besides a signal with a $\delta$ value ( $99 \mathrm{ppm}$ ). This suggests the presence of $\mathrm{MoO}_{2}{ }^{2+}$ groups, as in complexes $\mathbf{a}$ and $\mathbf{b}$. We assign the signal detected at $-60 \mathrm{ppm}$ to the phosphomolybdate moieties in the complex.

Signal intensity considerations and molecular models suggest that complexes e and f are 12:4 species (metalligand). The phosphate groups of the four ligand molecules are involved with the metal forming two phosphomolybdate moieties $\left[\left(\mathrm{OPO}_{3}\right)_{2} \mathrm{Mo}_{5} \mathrm{O}_{15}\right]^{6-}$; the carboxylate and the adjacent $\mathrm{OH}$ groups are coordinated to two additional $\mathrm{MoO}_{2}{ }^{2+}$ groups. A cyclic structure is proposed, represented schematically in Scheme 6, for one of the complexes ( $\mathrm{OH}$ groups are omitted for simplification).

Complexes e and $\mathbf{f}$ have equivalent phosphomolybdate moieties and different arrangements around the two $\mathrm{MoO}_{2}{ }^{2+}$ centres, resembling $\mathbf{a}$ and $\mathbf{b}$, respectively. Accordingly, complex $\mathbf{e}$ is slightly more stable than complex f. Scheme 6, involving a cis arrangement of the carboxylate groups, is assigned to complex e. Complex f differs by having a trans arrangement of the same groups. Deconvoluting the ${ }^{95} \mathrm{Mo}$ spectra, two signals are found for each of the complexes e and $\mathbf{f}$ with relative intensities of 5:1 suggesting that the four ligand molecules in each complex are equivalent magnetically.

\section{Conclusion}

This paper is an extension to phospho-sugar acids of a systematic study of the complexation of metal oxoions, namely tungstate and molybdate, with the main sugar acids, aldaric, ${ }^{5-7}$ alduronic ${ }^{8}$ and aldonic ${ }^{4,17-19}$ acids.

In our study, three complexes and six complexes were identified for tungsten(VI) and molybdenum(VI)

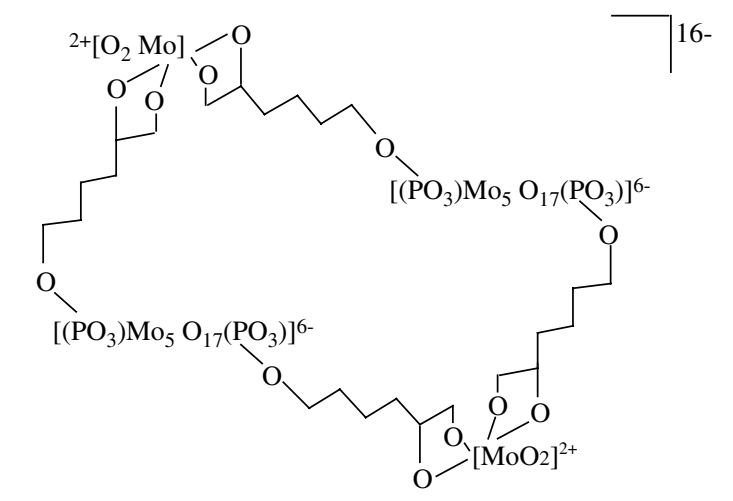


systems, respectively, which means a significant simplification with respect to the previously studied systems of D-gluconic acid with molybdate and tungstate. ${ }^{4}$ This is particularly so in the case of tungstate. Besides two 1:2 (metal-ligand) diastereoisomers, a very stable tetradentate 2:1 complex is formed. Although a terminal group (carboxylic group) is coordinated to the metal, the complex is stable because it involves a favourable $\mathrm{CO}_{2} \mathrm{H}$, $\mathrm{OH}-2, \mathrm{OH}-3, \mathrm{OH}-4$ (threo-threo-threo) configuration, as has previously been observed for the system M(VI)D-gluconic acid $(\mathrm{M}=\mathrm{Mo}, \mathrm{W}){ }^{4}$

Besides these species formed with both metals, molybdate is also able to form three more species, with the phosphate group also involved with the metal. One of them is a tetradentate species having one $\mathrm{Mo}_{2} \mathrm{O}_{5}{ }^{2+}$ centre, with the ligand being bound by the deprotonated $\mathrm{OH}$ groups in positions 3,4 and 5 and the phosphate group, the carboxylate and $\mathrm{OH}-2$ groups being free. Two novel 12:4 species are also detected. Each of these species has two equivalent phosphomolybdate $\left[\left(\mathrm{OPO}_{3}\right)_{2} \mathrm{Mo}_{5} \mathrm{O}_{15}\right]^{6-}$ moieties and two $\mathrm{MoO}_{2}{ }^{2+}$ centres. These can be thought as two 1:2 complexes bound together in a ring through two diphosphomolybdate moieties each derived from heptamolybdate by inclusion of two phosphate groups from the ligands. Such complexes were not found in the tungsten system, presumably because of the competing polymerization equilibria of tungstate.

\section{Acknowledgements}

This work has been supported by FCT, the Portuguese agency for scientific research. Thanks are due to Prof. H. D. Burrows for helpful discussion.

\section{References}

1. Nelson, D. L.; Cox, M. M. Lenhinger-Principles of Biochemistry; Worth: New York, 2000, Chapter 15.

2. Otake, H. Jpn Kokay Tokkyo Koho JP 11 21,545 [99 21,5459] (Cl. C09K3/14), 26 January 1999, Appl. 97/ 174,590, 30 June 1997; Chem. Abstr. 1999, 130 128821p.

3. Prendergast, J. E.; Her, Y.; Babu, S. V.; Li, Y.; Hariharaputhiran, M. PCT Int. Appl. WO 99 53,532 (Cl. H01L21/00), 21 October 1999; US Appl. 277,454, 26 March 1999; Chem. Abstr. 1999, 131, 294282d.

4. Ramos, M. L.; Caldeira, M. M.; Gil, V. M. S. Carbohydr. Res. 1997, 304, 97-109.

5. Ramos, M. L.; Caldeira, M. M.; Gil, V. M. S. Inorg. Chim. Acta. 1991, 180, 219-224.

6. Ramos, M. L.; Caldeira, M. M.; Gil, V. M. S.; van Bekkum, H.; Peters, J. A. Polyhedron 1994, 13, 1825-1833.

7. Ramos, M. L.; Caldeira, M. M.; Gil, V. M. S.; van Bekkum, H.; Peters, J. A. J. Coord. Chem. 1994, 33, 319-329.
8. Ramos, M. L.; Caldeira, M. M.; Gil, V. M. S. Carbohydr. Res. 1996, 286, 1-15.

9. Piantini, U.; Sørensen, O. W.; Ernst, R. R. J. Am. Chem. Soc. 1982, 104, 6800-6801.

10. Bax, A. D.; Morris, G. A. J. Magn. Reson. 1981, 42, 51-59; Bax, A. D. J. Magn. Reson. 1983, 53, 517-520; Wilde, J. A.; Bolton, P. H. J. Magn. Reson. 1984, 59, 343-346.

11. Kessler, H.; Griesinger, C.; Zarbock, J.; Loosli, H. R. J. Magn. Reson. 1984, 57, 331-336.

12. Lawrence, B. A.; Polse, J.; DePina, A.; Allen, M. M.; Kolodny, N. H. Curr. Microbiol. 1997, 34, 280-283.

13. Geraldes, C. F. G. C.; Castro, M. M. C. A. J. Inorg. Biochem. 1988, 33, 47-56.

14. Van Wazer, J. R.; Letcher, J. H. In Topics in Phosphorus Chemistry-P31 Nuclear Magnetic Resonance; Wiley and Sons: New York, 1967; Vol. 5, Chapter 3.

15. Martin, R. B.; Mariam, Y. H. In Metal Ions in Biological Systems; Siegel, H., Ed.; Marcel Dekker: New York, 1979; Vol. 8, Chapter 2.

16. Gorenstein, D. G. In Progress in NMR Spectroscopy; Emsley, J. W., Feeney, J., Sutcliffe, L., Eds.; Pergamon: Oxford, 1983; Vol. 16(1), Chapter 2.

17. Ramos, M. L.; Caldeira, M. M.; Gil, V. M. S. Carbohydr. Res. 1997, 297, 191-200.

18. Ramos, M. L.; Caldeira, M. M.; Gil, V. M. S. Carbohydr. Res. 1997, 299, 209-220.

19. Ramos, M. L.; Caldeira, M. M.; Gil, V. M. S. Carbohydr. Res. 2000, 329, 387-397.

20. Hläbi, M.; Chapelle, S.; Benaïssa, M.; Verchère, J.-F. Inorg. Chem. 1995, 34, 4434-4440.

21. Hläibi, M.; Benaïssa, M.; Chapelle, S.; Verchère, J.-F. Carbohydr. Lett. 1996, 2, 9-16.

22. Filowitz, M.; Klemperer, W. G.; Messerle, L.; Shum, W. J. Am. Chem. Soc. 1976, 98, 2345-2346.

23. Filowitz, M.; Ho, R. K.; Klemperer, W. G.; Shum, W. Inorg. Chem. 1979, 18, 93-103.

24. Miller, K. F.; Wenthworth, R. A. D. Inorg. Chem. 1979, 18, 984-988.

25. Maksimovskaya, R. I.; Burtseva, K. G. Polyhedron 1985, 4, 1559-1562.

26. Hastings, J. J.; Howarth, O. W. J. Chem. Soc., Dalton Trans., 1992, 209-215.

27. Caldeira, M. M.; Saraiva, M. E.; Gil, V. M. S. Inorg. Nucl. Chem. Lett. 1981, 17, 295-304.

28. Cavaleiro, A. M.; Gil, V. M. S.; Pedrosa, J. D.; Gillard, R. D.; Williams, P. A. Trans. Met. Chem. 1984, 9, 62-67.

29. Caldeira, M. M.; Gil, V. M. S. Polyhedron 1986, 5, 381-385.

30. Caldeira, M. M.; Ramos, M. L.; Gil, V. M. S. Can. J. Chem. 1987, 65, 827-832.

31. Gil, V. M. S. Pure Appl. Chem. 1989, 61, 841-848.

32. Berg, J.-E.; Brandänge, S.; Lindblom, L.; Werner, P.-E. Acta Chem. Scand. 1977, A31, 325-328.

33. Ramos, M. L.; Pereira, M. M.; Beja, A. M.; Silva, M. R.; Paixão, J. A.; Gil, V. M. S. J. Chem. Soc. Dalton Trans., 2002, 2126-2131.

34. Chapelle, S.; Verchère, J. F.; Sauvage, J. P. Polyhedron 1990, 9, 1225-1234.

35. Verchère, J. F.; Chapelle, S. Polyhedron 1989, 8, 333-340.

36. Matulová, M.; Bílik, V. Chem. Pap. 1990, 44, 703-709.

37. Pope, M. T. Prog. Inorg. Chem. 1991, 39, 181-257.

38. Chapelle, S.; Verchère, J. F.; Sauvage, J. P. Carbohydr. Res. 1991, 211, 279-281. 